\title{
The CSFs, Quality Governance, BPR Performance and Gaining Competitive Advantage
}

\author{
Mahmoud Masumi ${ }^{1,2}$ \\ ${ }^{1}$ Graduate School of Management (GSM), University Putra Malaysia (UPM), Malaysia \\ ${ }^{2}$ Faculty of Management, Marketing, Business and Economics, Putra Business School (PBS), Malaysia \\ Correspondence: Mahmoud Masumi, Graduate School of Management (GSM), University Putra Malaysia \\ (UPM), Malaysia. E-mail:nrn_828488@yahoo.com
}

Received: September 22, 2013

Accepted: November 4, 2013

Online Published: November 20, 2013

doi:10.5539/ijbm.v8n24p48

URL: http://dx.doi.org/10.5539/ijbm.v8n24p48

\begin{abstract}
Business process reengineering (BPR) is a popular management approach, which enables organizations to conduct substantial business and technological improvements. Successful implementation of BPR can assist organizations to change their old-fashioned practices into innovative processes through reorganizing and eliminating some processes and/or finding innovative ways to conduct business activities. Studies have shown, successful BPR implementation can. 1) create higher customer satisfaction, 2) increase productivity, 3) build higher flexibility in business processes, 4) improve organizational integrity which shall lead to sustainable competitive advantage for the firm. However, findings by different researches illustrate that up to $70 \%$ of BPR's failures are at implementation stage due to lack of understanding of involved factors by different levels of management in an organization.

This paper has exclusively developed the model, which can address the role of different factors in the implementation of Business Process Reengineering (BPR) performance and the ultimate outcome as competitive advantage. In addition, this research studies the influence of company size and business type as a moderator in the relationship between independent variables of study and BPR performance. The proposed model here aims to help planners in identifying a set of critical processes that are aligned with the firm's strategic performance and then become candidate processes for further implementation.
\end{abstract}

Keywords: business process reengineering, processes and procedures, quality governance, industry characteristics, competitive advantage

\section{Introduction}

The efficiency of administrative processes has become a major concern for many organizations during the last decades. Hence, to overcome such challenges, different tools and methods have been developed to enhance productivity and efficiency of organizational processes. Among various innovative methods considered, business process reengineering (BPR) has gained widespread attention from both academicians and industry directors. BPR is a popular management approach, which enables organizations to conduct substantial business and technological improvements. Hammer and Champy developed the concept of BPR in early 1990s. According to Hammer and Champy, BPR is a fundamental redesign of organizational processes to create a radical improvement in vital areas such as cost, quality, service, and speed (J. Champy, 1990, p. 120).

In a nutshell, successful implementation of BPR will assist organizations to change their old- fashioned practices into innovative processes through reorganizing and eliminating some processes and/or finding innovative way to do business activities. According to Farmer (2002), successful BPR implementation can 1) create higher customer satisfaction, 2) increase productivity, 3) build higher flexibility in business process, 4) improve organizational integrity which shall lead to sustainable competitive advantage for the firm.

Based on findings by (Simchi-Levi, Kaminsky, \& Simchi-Levi, 2003), the main focus of firm in the 1980s and 1990s was to develop new manufacturing technologies and supply chain management strategies which allowed them to reduce costs and consequently achieve sustainable competitive advantage in markets via lower overall price. However, thanks to advance technologies (e.g., Flexible Manufacturing System-FMS, Computer Aided Design-CAD, enterprise resource planning-ERP) which are affordable and accessible for many small \& medium 
companies; many firms could reduce manufacturing costs.

Thus, in today's dynamic market, companies can no longer enjoy better position in market simply by executing the traditional drivers by designing, manufacturing and selling a single product in advance to handle anticipated demand. To create completive advantage in market, firms should be able to react constantly and instantaneously to business environment changes. Business process reengineering (BPR) is one of the solutions that can help firms to achieve this goal (Trkman, 2010).

According to (Ozcelik, 2010; Trkman, 2010), Business Process Reengineering (BPR) refers to the fundamental rethinking and radical redesign of business processes to achieve rapid improvements, keeping in mind performance, cost, quality, responsiveness, and service. A business process is a series of steps which if implemented lead to a product or service. Through these business processes, organizations endeavor to add value for the customers, both internally and externally. BPR is a popular management tool for dealing with rapid technological and business changes (Ozcelik, 2010; Ranganathan, Teo \& Dhaliwal, 2011). However, findings by (Al-Mashari, Zairi \& Al-Mudimigh, 2010; Chiplunkar, Deshmukh \& Chattopadhyay, 2003), illustrates that up to $70 \%$ of BPRs failure is at implementation stage due to lack of understanding of involved factors by different levels of management in an organization.

Numerous analysis and assessments have been presented, most of which indicate that the major parameter for such high failure rates is attributed to the mismanagement of the firm during the implementations processes of BPR. While it has been suggested that BPR should be connected to the organization's goals, actual practice seems to be different. In many cases of failures, it appears that BPR has been viewed and applied at a segregated operational or tactical level, rather than strategic level. In many cases, BPR has failed as organizations were not well equipped to adopt and implement the radical redesign strategies. The failures may be attributed to the fact that BPR cannot keep up with the pace of environmental changes, resulting in failure to meet global organizational requirements. The solutions proposed here, focuses on setting long-term goals and subsequently customize BPR requirements during adoption and implementation phases based on the organization's needs. This would help consultants to identify a set of critical processes which are aligned with the firm's strategic performance and then become candidate processes for further implementation.

The failures of BPR may be attributed to; Either implementation process (procedures, process and governance), infrastructure (ITC facilities, technologies), human factors (leadership, employees), and company's characteristics (size and type of business) or a combinations of aforementioned factors.

To address this issue, the primary aim of this research is to develop the model that can address the role of different factors in the implementation of BPR, subsequent BPR performance and the ultimate outcome as competitive advantage. In addition, this research studies the influence of company size, business type as a moderator in the relationship between independent variables of study and BPR performance. The proposed model here aims to help planners in identifying a set of critical processes that are aligned with the firm's strategic performance and then become candidate processes for further implementation.

\section{Literature Review}

\subsection{History and Development of Business Process Reengineering}

The beginning of business process reengineering goes back to 1980s, when Western companies realized why the Japanese used the concept of processes together with just-in-time principles to improve manufacturing outcome. By applying these principles, they introduced a product-oriented factory layout. This involved partitioning of activities into separate cells organized by type of machine instead of the traditional functional departments. This introduced remarkable benefits for manufacturing facilities and production factories within Japanese companies.

According to (Mohapatra, 2013), these benefits included but not limited to improving coordination of workflow rate while reducing work-in-progress, such methodology reduced lead times dramatically and as a result the customer received a much better service. The concept of cells instead of departments led to multi-skilled workforces, who were responsible for their own quality inspections. Due to such innovative approach, the Japanese companies moved away from centralized control which was a feature of hierarchical organizations, and created semiautonomous cells with substantial decision-making power to direct and control their own activities.

Moreover, based on recent findings by (Oppenheim, 2011), he further elaborates that together with just-in-time principles, Japanese companies introduced Quality Circles. This was an introduction not only to total quality control but also to the principles of working in teams to streamline processes and reduce costs. While the tendency of companies in the United States was to check product quality at the final inspection, Japanese 
companies performed step-by-step quality control as part of the total production processes, whereas, US companies used their quality control departments to identify reject products at the end of the production processes. However, as these products' defects were only identified at the end of the production processes, related costs and customer dissatisfaction were unacceptably high. Japanese companies on the other hand did not use a quality control department, but included quality controllers as part of the project teams. They identified that by rejecting the defected products at a much earlier stage can reduce the cost and gain better yields, greater efficiency, and higher productivity (Black \& Porter, 1996; Mohapatra, 2013).

Based on the success achieved by Japanese manufacturing companies, organizations elsewhere started showing interests in innovative techniques to improve the business process. In the late half of the 1980s and early 1990s, companies in the United States and West Europe have introduced business process reengineering programs (BPR) as a substantial solution to improve performance. Implementation of BPR has given the competitive edge to companies to gain better market position in 1990s (Mohapatra, 2013; Oppenheim, 2011) (see table 1).

The concept of BPR first emerged in early 1990s (e.g., Davenport, 1993; Hammer, 1990; Hammer \& Stanton, 1999). Although, different definitions of BPR seem to exist. The most commonly used definition comes from Hammer et al., (1993), who defined business process reengineering as the redesign of business processes in order to dramatically improve performance in terms of cost, quality, service, and speed.

Table 1. Overview of recent literature in BPR

\begin{tabular}{|c|c|}
\hline The application of BPR in seismic data processing and interpretation management & Fu et al. (2013) \\
\hline The Need for BPR and Its History & Mohapatra (2013) \\
\hline $\begin{array}{l}\text { Are companies planning their organizational changes for corporate sustainability? } \\
\text { An analysis of three case studies on resistance to change and their strategies to } \\
\text { overcome it. }\end{array}$ & Lozano (2012) \\
\hline $\begin{array}{l}\text { A brief history of recent management paradigms. Lean for systems engineering } \\
\text { lean enablers for systems engineering }\end{array}$ & Oppenheim (2011) \\
\hline $\begin{array}{l}\text { Business process re-engineering in the logistics industry: a study of } \\
\text { success factors, and performance. }\end{array}$ & Shen et al. (2010) \\
\hline The critical success factors of business process management. & Trkman (2010) \\
\hline $\begin{array}{l}\text { Business process change: a guide for business managers and BPM and six sigma } \\
\text { professionals: }\end{array}$ & Harmon (2010) \\
\hline ERP implementation: An integrative methodology. & Al-Mashari et al. (2010) \\
\hline $\begin{array}{l}\text { Do business process reengineering projects payoff? Evidence from the United } \\
\text { States. }\end{array}$ & Ozcelik (2010) \\
\hline The role of BPR in the implementation of ERP systems. & Subramoniam et al. (2009) \\
\hline Reengineering the Corporation: Manifesto for Business Revolution & Hammer\& Champy (2009) \\
\hline $\begin{array}{l}\text { Exploring the relationships between information technology adoption and business } \\
\text { process reengineering. }\end{array}$ & Lee et al. (2009) \\
\hline Business process reengineering: critical success factors in higher education. & Ahmad et al. (2007) \\
\hline $\begin{array}{l}\text { Assessing the impact of information technology on firm performance considering } \\
\text { the role of intervening variables: organizational infrastructures and business } \\
\text { processes reengineering. }\end{array}$ & Albadvi et al. (2007) \\
\hline The state of business process reengineering: a search for success factors. & Paper \& Chang (2005) \\
\hline $\begin{array}{l}\text { Application of principles of event related open systems to business process } \\
\text { reengineering. }\end{array}$ & Chiplunkar et al. (2003) \\
\hline Business process re-engineering in Malaysian banks and finance companies. & Khong \& Richardson (2003) \\
\hline BPR implementation process: an analysis of key success and failure factors. & Al-Mashari \& Zairi (1999) \\
\hline Implications of business process management for operations management. & Armistead \& Machin (1997) \\
\hline $\begin{array}{l}\text { Business process re-engineering and process management: a survey of current } \\
\text { practice and future trends in integrated management. }\end{array}$ & Zairi \& Sinclair (1995) \\
\hline
\end{tabular}

\subsection{Leadership and BPR Performance}

According to Elmuti and Kathawala (2011), leaders in an organization which is implementing change, need to be visionaries, communicators, motivators, and leg breakers. Leadership has to be committed to the change. One issue that appears to remain as a problem, is middle managements' view of the change and unwillingness to 
change. Paper and Chang (2005) suggested, top-down imperatives should be tempered with involvement from people along the process path. Change management, however, is very difficult because people tend to react negatively to it. Furthermore, cultural change seems to be the most difficult challenge of BPR.

According to (Den Hartog, Boon, Verburg \& Croon, 2012), leadership will aid in increasing the trust between leaders and employees by leadership communicating honestly with employees and demonstrating they are embracing the change effort, which will increase job satisfaction.

Change Management/Resistance to Change Theorists (Della Torre \& Solari, 2012; Lozano, 2012; Peccei, Giangreco \& Sebastiano, 2011), have suggested that leadership needs to address the issue of change management at all levels within the organization.

Some of the recommended methods aimed at reducing resistance to change and hence moving the organization towards a culture that embraces change are communications with employees, empowering employees, allowing employees to make decisions, and training. According to Lewin, who works in organizational change, found these methods to be successful. Both organizational change theorists and specifically BPR theorists (Al-Mashari, et al., 2010; Baer \& Frese, 2003; Berthon, Mac Hulbert, \& Pitt, 2004; Black \& Porter, 1996; Brown \& Leigh, 1996; Caron, Jarvenpaa, \& Stoddard, 1994; J. A. Champy \& Nohria, 1996) agree with Lewin's findings. Therefore, to examine the relationship between leadership support level and BPR performance, the following hypothesis is developed.

Proposition 1: There is a relationship between leaders' support level and BPR performance.

\subsection{Employee and BPR Performance}

According to the literature review, it has been often noted that 'people are the bedrock of every organization', and as there are many people, so are emotions, concerns, beliefs, intelligence, inclinations, etc. Hence, the presence and ability to propel individuals to act within the confines defined in a successful implementation becomes imperative. Hurt et al. (1977) was one of the earliest researchers to attempt to define innovativeness, expressing it as a 'willingness to change'. Midgley and Dowling (1978) articulate innovativeness as a form of innate personality trait. Goldsmith and Hofacker (1991) define it as both an attitude and a behavior. However, Hjalager (2010) ascertains that 'innovativeness conveys some behavioral change in response to a stimulus'. Zaltman et al. (1971) and Berthon et al. (2004) depict innovativeness as 'open-mindedness', 'enterprising', 'willingness to change', 'ability to innovate' or to be creative. This conceptualization underscores the current authors' emphasis on what Mengesha and Common (2006) refer to as a firm's receptivity and "willingness to forgo old habits and try untested ideas" (2006, p. 66). Similarly, (Cotte \& Wood, 2004) conceptualize it as the tendency to embrace change and try new things.

The second human factor which can influence employees to be committed to BPR is self-efficacy or sense of purpose and effectiveness. Theory of self-efficacy triangulates the relationship between the individual's personality, behavior and environment. Simply described, self-efficacy determines whether tools and capabilities are necessary to accomplish specific tasks. Studies show that increasing self-efficacy has been claimed to improve the rate to accept the novel phenomena (in this study BPR Implementation) by individual.

Another personal factor which can influence the commitment to BPR implementation is the individual fear of change. Fear of change may be attributed to more than a tendency toward regularity. BPR can be associated with many unknown consequences. According to Hopkins (2003), the delay in an organization's response which may be as a result of a closed mindset of management, delusions of superiority, ingrained strategies, rigid assumptions about the industry and competition, entrenched culture or rigid structure systems which further emphasize resistance to change, cultivates a good and conducive atmosphere where radical changes within the organization can be implemented; such that a collapse of this resistance will in itself generate an enormous pressure that would yield a more than proportionate gain.

According to Griffith (2005) "organizations need to create organizational cultures that permit risk taking and that do not punish employees for failures, but one that allows employees to learn from their mistakes" (p. 42). Schein's (2004) definition of culture is a pattern of shared basic assumptions that was learned by a group as it solved its problems of external adaptation and internal integration, that has worked well enough to be considered valid and, therefore, to be taught to new members as the correct way to perceive, think, and feel in relation to those problems (p. 17).

BPR studies conducted by (Edward \& Mbohwa, 2013; Fu, et al., 2013) have found that to implement BPR successfully, leadership needs to create a culture that embraces change. According to Agrawal and Cockburn (2003), for employees to be innovative, there needs to be a culture that is willing to embrace change and take 
risks. According to Paper and Chang (2005), in order for innovation to increase, leadership has to remove the fear of failure and promote risk taking. Banutu-Gomez (2002) suggested that company should be willing to trust employees to make decisions even if they are the wrong decisions and encourage employees to learn from their mistakes. To test the relationship between employee willingness and level of performance, the following hypothesis has been developed:

Proposition 2: There is a relationship between employees' willingness and level of BPR performance.

\subsection{Infrastructure and ITC Supports and BPR Performance}

Additional studies implemented and developed by (Albadvi, Keramati, \& Razmi, 2007; Herzog, Tonchia, \& Polajnar, 2009; Shen \& Chou, 2010), have suggested that organizations implementing BPR need to have a good ITC supports and technology infrastructure. Without a good infrastructure, it will be harder to implement new systems and integrate new business processes. Moreover, previous researchers stated that ITC as an indispensible enabler is needed to achieve the best results in BPR implementation, and particularly its integration in processes should be utilized in redesign activities.

According to (Motwani \& Akbulut, 2009), IT is introduced as a critical component and even a natural partner of BPR, which has a continuous and important role in BPR projects. Many authors have described that successful application of IT is effective in the success of BPR, both during adoption and implementation processes. Contrarily, overlooking the role of IT can result in failure, as assessed from literature by (Motwani \& Akbulut, 2009; Ozcelik, 2010).

According to BPR studies developed by (J. Champy, 1990; Chapman \& Kihn, 2009), they suggested that in order for organizations to excel, to find that breakthrough performance, they need to use information systems or technology to enable new processes. Just automating the old system will not gain the benefits of sharing information across functional boundaries. Grover and Markus, (2008) found that within the three types of information systems developed; intra-functional (e.g. within a function), inter-functional (eg., crossing functional areas), and inter-organizational (e.g. crossing multiple organizations), the biggest benefits were inter-functional or inter-organizational projects.

According to Rivard et al. (2004), "technology plays an important role in both driving and facilitating change. Technology increases response, helps coordinate actions, and makes possible the development of new products and services" (p. 11). Moreover, the studies conducted by (Hammer, 1990; Hammer \& Champy, 2009; Hammer, et al., 1993; Hammer \& Stanton, 1999), have suggested an organization should have a specific framework to see connection or integration of IT with other departments in order to benefit from them so as to enable BPR implementation.

According to current studies, IT is one of the major factors, which help putting all the systems together and in place. IT plays an important and central role in the BPR adoption, implementation and subsequent performance to achieve competitive advantage. As Khalilet al., (2013) indicated, most of the initiatives of BPR came from the IT department, which is true in substantiating the fact that BPR started from the IT department, which tried to find a new way of doing things effectively and efficiently. Thus, to test the relationship between infrastructure and IT and BPR performance the following hypothesis has been developed:

Proposition 3: There is a relationship between infrastructure and ITC and BPR performance.

\subsection{Processes, Procedures and BPR Performance}

In order to successfully implement business process reengineering projects, companies need to follow a systematic approach. Although there is no set formula (Caron et al., 1994), several different approaches have been proposed. Evans (1994) uses a bridging metaphor to describe a broad framework for BPR projects. He proposes a four-stage process: (1) defining vision; (2) outlining the current business process; (3) creating a plan for the redefined process; and (4) implementing the plan. This seems feasible but provides little insight into how the new process should be designed.

In the process of BPR, business management and operation procedures are standardized. Meanwhile such platform can provide information about materials preparation and cost on entire project dynamically and concurrently, which can help enterprises to realize target cost management. Ahmad et al., (2007) found that a proper organizational system is important for the success of BPR. Systems should include elements such as common interests, values, and decision making, which showed linkages to culture and structure in various case studies findings.

To survive in a highly competitive business environment, companies are subject to continuous change of their 
business processes. Therefore, creativity and innovation is essential for 'BPR Performance Initiatives' to accomplish successful achievements. An initiative to change a business process should come from the top, i.e. from the top management, so the transition of process ownership is very important and necessary. The employees, who work with new processes have to own them, otherwise the project, will tend to fail (Caron, et al., 1994). Most companies lack process owners or they are defined to a minor extent, which is the consequence of a traditional organization of people and their thinking, which is not process oriented (Hammer \& Champy, 2009)

According to (Hammer \& Champy, 2009), the task of a process owner is not to do business reengineering but to make it happen. It is therefore, not surprising that process owners should be the persons of trust and confidence with quite high reputation, respect, toleration and readiness to change. Al-Mashari et al., (2010) cited undetermined process owners as one of the factors leading to the failure of BPR, while Grover and Markus (2008) emphasized the lack of process owners as a barrier in BPR.

Non-existent or inadequate documentation can be another reason for problems during BPR implementation. Guha and Kettinger (1993) paid specific attention to the importance of clearly understand the existing business processes before implementing BPR; therefore, processes need to be documented first, which is also supported and endorsed by Donovan (2002).

According to recent studies conducted by (Grover \& Markus, 2008), it is emphasized that 'Inappropriately defined business processes can also be a reason for BPR failure'. Even too broad or too narrowly defined processes can lead to the failure of a BPR project.

Several authors (Grover \& Markus, 2008; Meadows \& Merali, 2003; Rich \& Bateman, 2003), have also acknowledged 'the articulation of a strategic intent to diligently focus on existing scenario and the requirements for redesigned processes'. Business process capabilities provide significant strategic opportunities (Roth and Jackson, 1995) and the processes themselves may be viewed as strategic assets. Armistead and Machin (1997) provided some examples where companies have linked their long-term plans with annual plans for key business processes. Process management is more than a way to improve individual processes, it is a way to operate and manage a business (Hammer \& Stanton, 1999). Therefore, to test the relationship between the process and procedures and BPR implementation, the following hypothesis has been developed:

Proposition 4: There is a relationship between the processes and procedures and implementation of BPR.

\subsection{Quality Governance and BPR Performance}

Furthermore, according to Jurison $(1999$, p. 28), the purpose of project control is: "to keep the project on course and as close to the plan as possible, to identify problems before they happen and to implement recovery plans before unrecoverable damage is done". Al-Mashari et al., (2010) pointed out that "having a comprehensive measurement system provides a feedback mechanism to track implementation efforts, identify gaps and deficiencies in performance, and recommend the necessary actions to fine tune the situation in hand in order to achieve the desired business centred outcomes. Based on earlier findings by Kale (2000), it reaffirms that measures for innovative process reengineering should be: visible, meaningful, small in number, applied consistently and regularly, quantitative and involving personnel closest to the process. Although there is the recognition of the needs to control and monitor a redesigned process and link it to continuous improvement programs, many studied methods, did not reflect the recognition of above mentioned requirements.

Since the implementation of BPR is reengineering project that aim to improve the business process therefore, having the appropriate governing process that can monitor and control the BPR implementation at each stage, appears to be vital and necessary. Thus, to test the role of the quality of governance in the implementation of BPR in oil and gas industry, the following hypothesis is developed:

Proposition 5: There is a relationship between the quality of governance of BPR and BPR implementation.

\subsection{Intervening Role of Company Size and Company Business on the Relationship between CSFs and Implementation of $B P R$}

Literature review emphasizes that company size is one the factors that can influence any business strategy implementation process. BPR implementation in a company involves people and recourses from all levels of company and the size can directly influence the effectiveness of some sub-strategy implementation as well. For example, in the case of employees and human recourse factor, usually in smaller companies, individuals are multi-task players in comparison to large companies, where almost all tasks are highly specialized and focused, in this case the size might influence the level of autonomy in decision making or in broader perceptive to the level of staff empowerment. 
Moreover, in medium size companies, usually the organization structure is more flat with fewer hierarchies which can lead to less complicated procedures and more lenient business process compared to big companies that usually have more layers of decision making and less autonomy for managers. On the other hand, in the case of facilities and infrastructure, it seems obvious that bigger companies have more financial recourses and economic of scale and scope to acquire the latest technologies and infrastructures compared or medium size companies that focus primarily on particular business models. To test the moderation role of company size on the relationship between CSFs (leadership, people, infrastructure and IT, process and procedures and quality governance) and implementation of BPR, the following hypothesis has been developed:

Proposition 6: Company size (medium/big) can moderate the relationship between CSFs and implementation of BPR.

Another factor that can play a major role in the proper implementation of BPR is the companies' nature of business in the oil and gas sector. Therefore, to test the moderation role of the type of industry on the relationship between CSFs (leadership, people, infrastructure and IT, process and procedures and quality governance) and implementation of BPR, the following hypothesis has been developed:

Proposition 7: Industry characteristics can moderate the relationship between CSFs and implementation of BPR.

\subsection{BPR Performance and Gaining Competitive Advantage}

Organizations are continuously seeking for innovative ways to operate in order to survive in a competitive business environment. The increasing competitive pressure that organisations currently face forces them to find ways of minimizing the time it takes to develop the product, bring products to the market and offer efficient and effective service to clients, whilst at the same time, maximizing company's profits. Many leading organizations have conducted BPR in order to improve productivity and hence, gain competitive advantage.

However, there are some cases that even if company could successfully implement the BPR, the outcomes were not up to their expectation as the objectives of BPR were not set accurately from the first step. In fact PBR is a tool for change management and modifying the business processes, and if the company has failed to set the suitable goals and objectives for PBR adoption and implementation, even though, company may be able to implement it successfully, the outcome might not be in the favour of company's goals, which is gaining better position in the market place and achieving competitive advantage. Thus, to test the relationship between the success rate of BPR and gaining competitive advantage in the oil and gas industry, the following hypothesis has been developed:

Proposition 8: There is a relationship between the performance success rate of BPR and gaining competitive advantage in the market. 


\subsection{Diagrammatic Conceptual Framework}

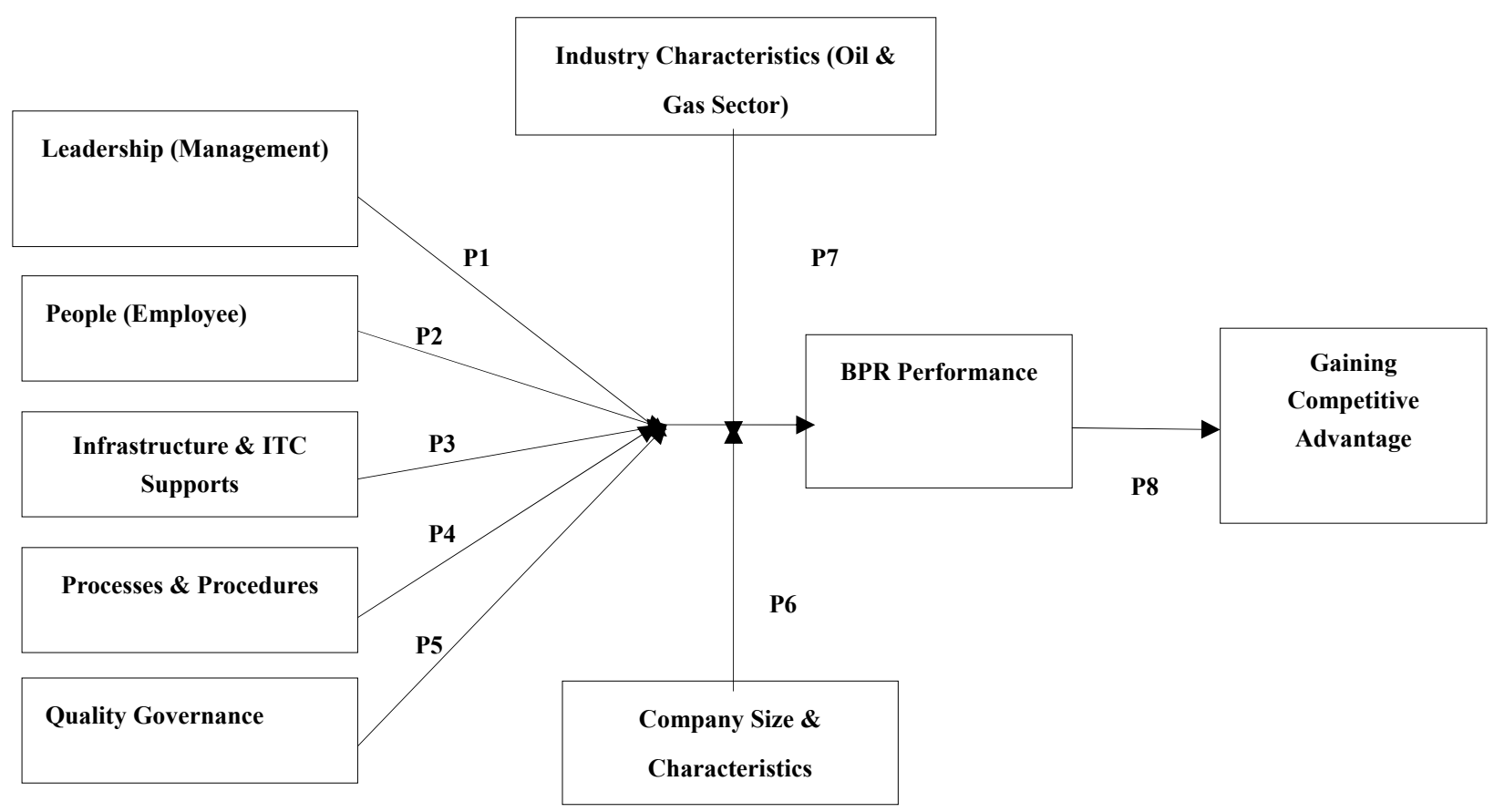

Figure 1. Diagrammatic conceptual framework

\section{Research Design and Methodology}

\subsection{Research Method}

Theoretically, there are two major research methods, quantitative and qualitative. Each method is considerably different in the way data are collected and analyzed. The two research methods have advantages and disadvantages when applied to a particular phenomenon. Both methods are widely used in social research including business research (Babbie, 2004; Saunders et al., 2007, p. 123).

Additionally, in recent years, evaluators of educational and social programs have expanded their methodological repertoire with combining quantitative and qualitative method. The third method was born. Scholars call it "Mixed Method". Mixed Methods research is becoming an increasingly popular approach in several areas, and it has long been called for as an approach for providing a better understanding of research problems (C. Greene, Caracelli \& F. Graham, 1989). According to Creswell (2009) a mixed methods way of thinking is an orientation towards social inquiry that actively invites us to participate in dialogue about multiple ways of seeing and hearing, multiple ways of making sense of the social world, and multiple standpoints on what is important and to be valued and cherished.

A clear understanding of different philosophical standpoints is essential for a researcher to clarify his/her fundamental beliefs and to justify 'why', 'what', and 'how' particular research practices are chosen. Research philosophy is discussed from a variety of perspectives. For instance, Babbie (2012a) uses the term social science paradigm which is defined as "a model or framework for observation and understanding, which shapes both what we see and how we understand it". There are four major philosophical traditions which are remarkably opposite viewpoints:

- Positivism;

- Social Constructivism;

- Advocacy / Participatory;

- Pragmatism.

According to the Sophonthummapharn (2009), Positivism and Constructivism are more important than others.

In conclusion: Based upon personal considerations, the author's belief towards the world inclines to positivism 
more than social constructivism. That is because, 1)-This study is based on sense, experience and positive verification and according to the positivism philosophy, just this type of a research can be authentic knowledge.

2)-According to this philosophy, the goal of any research is to explain and predict and the ultimate goal of current study is to predict and explain the CSFs which shall Impact Quality Governance in BPR implementation among Oil and Gas Companies. 3)-According to positivism philosophy, scientific knowledge is testable. Research can be proved only by empirical means, not argumentations. Research should be mostly deductive, i.e. deductive logic is used to develop statements that can be tested (Laudan, 1996). In current study, also theory leads to hypothesis which in turn leads to discovery and/or study of evidence. For all above reasons, the philosophy of this study is bested on positivism.

The beliefs and experiences of a researcher somehow influence the way a particular research project is conducted.

In particular, the way a researcher views environments or the world surrounding him/her will underlie the choice of which research practices should be used including research approaches, research strategies, etc. In the research community, the researcher's beliefs and experiences are called research philosophy or sometimes called the research paradigm (Uddin \& Hamiduzzaman, 2011).

This study used a fixed quantitative design. This non-experimental survey measurement strategy did not manipulate the environment, but simply measured it (Robson, 2002). "The research design involves a series of rational decision-making choices relating to the purpose of the study, the study setting, the type of investigation, the temporal aspects, the unit of analysis, the type of sample to be used as well as the data collection methods, measurement and analysis" (Sekaran, 2003, p. 117). This study investigates and examines "The CSFs of Quality Governance in BPR Implementation among Oil and Gas Companies". A correlational quantitative and explanatory (Hypothesis Testing) research used to test the hypotheses. This study applied correlation statistics to each learning. The study uses appropriate statistical tests that encouraged results with validity, reliability, generalizability, objectivity, credibility, minimal bias, and replicability.

\subsection{Time Frame (Time Dimension or Time Horizon)}

Data collection time horizon for this study is cross-sectional. Cross-sectional study; is based on observations of a sample, population, or phenomenon that are made at a single point in time (Babbie, 2004). Most research projects, especially in business, are cross-sectional studies because they often face a certain level of constraint, e.g. time, budget, staff, and resource allocation.

The list of companies consisting of email address, telephone number and identified authorized person has been developed. Data will be obtained from industry directory and through the researcher's networks. A paper (via mail) or electronic (email and Google questionnaire) self-administrated questionnaire will be sent to the participants who have given the initial approval to participate in this research and have experience in implementation of PBR.

\subsection{Data Collection Method}

Data collection is a term used to describe a process of preparing and collecting data. Data collection methods are an integration part of research design (Sekaran, 2003). Several data collection methods have been known, each one has its own advantages and disadvantages. Proper research with the use of appropriate methods greatly enhances the value of the research. The purpose of data collection is to obtain information to keep on record, to make decisions about important issues, to pass information on to others. Primarily, data are collected to provide information regarding a specific topic. Data can be collected in a variety of ways, in different settings, fields or methods which include interviews, face to face interviews, telephone interviews, computer assisted interviews, interview through the electronic media; Questionnaires that are either personally administered, sent through the email or electronically administered; Observation of individuals and events with or without videotaping or audio recording and a variety of other motivational techniques such as projective testes (Sekaran, 2003).

\subsection{Questionnaire Development}

The questionnaire consisted of several types of questions. The general questions were constructed to collect basic information about respondents such as questions relating to demographic and basic information of the company. The questions included type of industry, size, the existence of company in business and the main regional business focus.

The instrument for data collection of this study is a questionnaire, which consists of four parts. The first part of questionnaire covers the questions regarding the level of leadership involvement and style in implementation of 
BPR project. In this part, participants are asked to rate their idea about leadership in organization $(1=$ Very Low, 6 = Very High). Second part of questionnaire focuses on the involvement of employees toward BPR project, level of infrastructure and ITC supports, accuracy of BPR procedure and process, and quality governance of BPR project $(1=$ Very Low, $6=$ Very High $)$.

The third part of questionnaire covers questions about BPR implementation success and the rate of gaining competitive advantage by improving the quality, time management, customer satisfaction, human resource management and flexibility to respond to market demand $(1=$ Very Low, $6=$ Very High $)$ (see table1). The last part of the questionnaire focuses on demographic information of the company such as: company's size (medium, big), industry characteristics, and business type \& characteristics.

\subsection{List of Measurement Items}

Table 2. List of measurement items

\begin{tabular}{|c|c|c|}
\hline Variables & Question & Adopted/Adapted Source \\
\hline Leadership/Management & $\begin{array}{l}\text { 1- Extent to which the top executive (responsible for company profit } \\
\text { or loss) assumes responsibility for changes. } \\
2-\quad \text { Acceptance of responsibility for changes that announce greater } \\
\text { profit, lower costs, greater quality etc. by department heads within the } \\
\text { company. } \\
\text { 3- Degree to which top management (top executives and department } \\
\text { heads) support processes improvement. } \\
\text { 4- Degree of participation by department heads in the reengineering } \\
\text { process. } \\
\text { 5- Level to which top management identifies with the reengineering } \\
\text { goals. } \\
6-\quad \text { Specificity of reengineering goals within the company. } \\
7-\quad \text { Development \& validation of BPR variables } 5829 \\
8-\quad \text { Downloaded } \\
9-\quad \text { Comprehensiveness of the goal - setting processes within the } \\
\text { company. } \\
10-\quad \text { Extent to which reengineering goals and policy are understood } \\
\text { within the company. } \\
11-\quad \text { Importance attached to reengineering by the company's top } \\
\text { management in relation to cost and schedule objectives. } \\
12-\quad \text { Attention to reengineering results at company top management } \\
\text { meetings. } \\
13-\quad \text { Degree of understanding BPR within the company. }\end{array}$ & Herzog et al. (2009) \\
\hline People and Culture & $\begin{array}{l}\text { 1- Degree of employee incorporation when decision-making about } \\
\text { BPR. } \\
2-\quad \text { Level to which in-company education, about the need for changes, } \\
\text { is built. } \\
3-\quad \text { Level to which employee contribution to better process operating } \\
\text { is recognized. } \\
4-\quad \text { Extent to which the benefits of BPR are exposed within the } \\
\text { company. } \\
5-\quad \text { Employees resistance to the new system } \\
6-\quad \text { Organization that is incapable of adapting or refuses to make the } \\
\text { necessary changes }\end{array}$ & Herzog et al. (2009) \\
\hline $\begin{array}{c}\text { Processes and } \\
\text { Procedures }\end{array}$ & $\begin{array}{l}\text { 1- Use a well-trained, diversified, expert team } \\
\text { 2- } \quad \text { Use a re-engineering team well-informed in BPR methods } \\
\text { 3- } \quad \text { A BPR team demonstrates dedication to the project } \\
\text { 4- A BPR team shares a clear vision and understanding of BPR } \\
\text { success } \\
\text { 5- Effective use of external consultants with specialized skills, } \\
\text { experience and require know-how of the organization in facilitating BPR }\end{array}$ & Al-Mashari \& Zairi (1999) \\
\hline
\end{tabular}




\begin{tabular}{|c|c|c|c|}
\hline & \multicolumn{3}{|c|}{ projects } \\
\hline & 6- & \multicolumn{2}{|l|}{ Have clear criteria to select what should be re-engineered } \\
\hline & & \multicolumn{2}{|l|}{ Identify the appropriate process for BPR } \\
\hline & \multirow{2}{*}{\multicolumn{3}{|c|}{$\begin{array}{l}\text { 8- The re-engineering effort is directed at key business processes } \\
\text { rather than organizational units }\end{array}$}} \\
\hline & & & \\
\hline & \multirow{3}{*}{\multicolumn{3}{|c|}{$\begin{array}{l}\text { 9- Establish performance improvement goals for processes } \\
\text { 10- Integrity of the present state process review. } \\
\text { 11- Concentration on the key business processes for the operation of } \\
\text { the company (making an offer, new product development, etc.). }\end{array}$}} \\
\hline & & & \\
\hline & & & \\
\hline \multirow{10}{*}{ Infrastructure and ITC } & & Alignment of IT infrastructure and BPR strategy & \multirow[t]{10}{*}{ Al-Mashari \& Zairi (1999) } \\
\hline & $2-$ & Building of effective IT infrastructure & \\
\hline & $3-$ & Adequate IT investment and sourcing decisions & \\
\hline & & Adequate measurement of IT infrastructure effectiveness on BPR & \\
\hline & & Increasing IT function competency & \\
\hline & & Proper information system integration & \\
\hline & & Effective use of software tools & \\
\hline & & Extent to which data, enabled by IT, are used for the assessment of & \\
\hline & & achievement and setup of business strategy (higher quality, shorter & \\
\hline & del & ery times, lower costs, greater flexibility, etc.). & \\
\hline \multirow{6}{*}{ Quality Governance } & & Lack of appropriate follow-up and monitoring & \multirow[t]{6}{*}{ Chang (2005)/ Herzog et al. (2009) } \\
\hline & & $\begin{array}{l}\text { Lack of appropriate indicators for following up and assessing } \\
\text { rmance }\end{array}$ & \\
\hline & $3-$ & Request for continuous improvement. & \\
\hline & $4-$ & Use of flow diagrams to represent process activities. & \\
\hline & & Quality function deployment. & \\
\hline & $6-$ & Flow synchronization. & \\
\hline \multirow{7}{*}{ BPR Performance } & & Alignment of BPR strategy with corporate strategy & \multirow[t]{7}{*}{ Lockamy \& Smith (1997) } \\
\hline & & Tying of BPR project goal to key business objectives & \\
\hline & & Building of BPR vision by forming a clear and compelling & \\
\hline & \multicolumn{2}{|r|}{ vision for future processes } & \\
\hline & \multirow{2}{*}{\multicolumn{2}{|c|}{$\begin{array}{l}\text { 4- Process selection for BPR have a significant impact on client } \\
\text { satisfaction and delight }\end{array}$}} & \\
\hline & & & \\
\hline & \multicolumn{2}{|r|}{$\begin{array}{l}\text { 5- Process selection for BPR have a significant impact on } \\
\text { financial performance }\end{array}$} & \\
\hline \multirow{18}{*}{ Competitive Advantage } & & Quality & \multirow[t]{18}{*}{ Herzog et al. (2009) } \\
\hline & a) & Internal quality & \\
\hline & b) & External quality & \\
\hline & & Time & \\
\hline & a) & Internal time performance & \\
\hline & b) & External time & \\
\hline & $3-$ & Flexibility & \\
\hline & a) & Product modification flexibility & \\
\hline & b) & Process modification flexibility & \\
\hline & c) & Managerial flexibility & \\
\hline & 4- & Customer satisfaction & \\
\hline & a) & General indicators of customer satisfaction & \\
\hline & b) & Direct customer cooperation & \\
\hline & $5-$ & Human resources and employee satisfaction & \\
\hline & a) & Work absence & \\
\hline & b) & Employee qualification & \\
\hline & c) & Promotion and personal development & \\
\hline & d) & Working experiences & \\
\hline
\end{tabular}

\subsection{Data Processing and Data Analysis}

Data Processing: Is a step that entails various activities such as data entry of responses, screening the data and 
selecting the suitable data analysis strategy (Churchill and Lacobucci, 2009; Sekaran, 2007). In order to identify data entry errors, data screening is performance which include; missing data, outlier, normality, reliability, validity, descriptive data and test of response bias (Al-Majali, 2011).

Data Analysis: According to Sekaran (2007) researchers analyze data for three objectives:

1) Getting a feel for the data;

2) Testing the goodness of the data;

3) Testing the hypotheses developed for the research.

In current study, two types of analyses have been used; descriptive analysis and inferential analysis. Descriptive statistics such as means, standard deviations, frequency, percentage, reliability coefficients, zero-order correlations, and ranges were computed for all the items in the surveys. SPSS software will utilize to carry out some of the statistical tests and to measure the frequency distribution and correlation matrixes. The reliability of the questionnaire and internal consistency of the data was estimated by calculating Cronbach Alpha for each scale. On the other hand, in order to analyze data and do the hypothesis testing and to test the proposed relations among the variables in the model and consequently to achieve the objectives, this study will use the Structural Equation Modeling (SEM) and its application, AMOS.

SEM is a multivariate technique, which combines components of multiple regression and factor analysis (Hair et al., 2010). This technique is considered adequate for the type of investigation carried out by this study since it allows for answering questions that involve multiple regression analysis of factors among a single measured dependent variable and a group of measured independent variable (Ullman, 2007). According to Hair et al. (2006), SEM is used to test theoretical models. A structural equation model normally consists of two types of models:

- The Measurement Model that represents the theory and which specifies how measured variables come together to represent latent factors.

- The Structural Model which represents the theory specifying how constructs are related to other constructs in the model.

SEM has been used to measure the relationships between the independent variables and dependent variables. Since this study required the hypothesized models to be tested for the best-fit, SEM seemed to be the appropriate analysis method as it produces more comprehensive overall goodness-of-fit than those found in other traditional methods.

The best-known SEM statistical programs include LISREL (Linear Structural Relationship) and AMOS (Analysis of Moment Structure. AMOS was developed by Arbuckle and Wothke (2006) and has a number of advantages over the other programs. AMOS as a software package (Arbuckle, 1997; Byrne, 2001; Tabachnick \& Fidell, 2001) will be used for SEM as it is user-friendly software which provides a graphical user interface, which is easy to understand. The package has a user-friendly graphical interface and method of specifying structural models (Tabachnick \& Fidell, 2001).

In conclusion, in order to analyze data, current study has used "SPSS" software and "AMOS" software. SPSS has been used because: 1)-SPSS software can measure the frequency distribution and correlation matrixes by carrying out some of the statistical testes. 2)-The reliability of the questionnaire and internal consistency of the data must be estimated and SPSS will enable the researcher to achieve this by calculating Cronbach Alpha for each scale.

On the other hand, AMOS has been used because: 1)-It is easy to use the program to show hypothesized associations among variables. 2)-It is widely used in the field of management studies for the structural equation models.

Confirmatory Factor Analysis (CFA) can also be used to assess measurement invariance with respect to gender and other demographic variables, which is part of the investigation carried out in this study.

\section{Research Implications}

\subsection{Theoretical Implications}

The theoretical implications of the research include:

1) The CSFs of QG in BPR Implementation among O\&G Companies researched \& explored in depth;

2) Looking at BPR from Organizational Perspective; 
3) Overcoming the limitations of the study;

4) Expanding on Management Strategy Theory;

5) Providing the empirical evidence that individual characteristics or technological characteristics alone are not sufficient to drive the intention, adoption and implementation of successful BPR;

6) Finding significant relationships between (Management, Employees, Infrastructure \& ITC Supports, Processes \& Procedures, Quality Governance, Industry Characteristics, Company Size \& Business Characteristics) and Successful BPR Implementation, Quality Performance leading to Organization's Competitive Advantage;

7) Creative and Innovative Quality Governance has significant relationship with high success rate of BPR implementation, evolutionary performance and firm's competitive advantage on measurement of many pivotal aspects.

\subsection{Practical Implications}

Using framework as a research tool in examining determinant factors in the decision to implement BPR as well as other management innovations in other context:

1) The research results should support the research framework and hypothesis as well as providing significant contributions to the Body of Knowledge, which will guide the business planners to identify and execute the CSFs influencing QG in successful BPR implementation, higher performance to gain competitive advantage;

2) Firms need to identify, acquire and retain customers, to understand Clients' requirements, and to develop customer loyalty in order to maintain and increase profits, So, the achievement of the research goals \& objectives would guide academic research to explain, recognize and explicate the CSFs influencing QG in successful BPR implementation, Firm's performance to gain competitive advantage;

3) The results shall emphasize that policy makers have to give more supports towards the BPR changes from top management, greater flexibility, emerging market and customer orientation, having a better perception of ITC solutions, systems, processes \& procedures, improve QG, increasing competitiveness and keeping more intimate relationships with employees so as to achieve higher levels of engagement with them to maintain enhanced performance resulting in firm's greater competitive advantage;

4) Policy makers in the O\&G Sector, need to examine their current communication tactics in order to develop more effective ways of business conduct with their clients \& suppliers of materials and services;

5) O\&G managers should consider that BPR is a multidimensional phenomenon that should be considered in all levels of the industry; therefore, if they are going to achieve the greater value that can be created by BPR implementation, they should design a suitable organization-wide customer/employee (short \& long term) strategy with specific goals.

\section{Discussion}

BPR has been considered as an important concept to reshape business organizations for achieving breakthrough improvements in performance. In fact, BPR involves relatively extensive work, not only in emphasizing the concept of processes, but also by requiring understanding in various parts of the organization on topics such as: change management, job definition, processes redesign and reengineering of relevant scope of work, human resources, etc.

The primary contribution of this research is the conceptualization and empirical testing of the CSFs of Quality Governance in BPR implementation and the relevant processes, systems and the subsequent impacts on quality leadership and management functions and measurement of BPR performance leading to competitive advantage for companies.

Additionally, a clear understanding of firms' management and staff attitude and behavior will help in designing appropriate policies and initiatives to enhance $\&$ accelerate BPR performance in gaining competitive advantages through utilizing appropriate infrastructure and ICT support and pertinent technologies in companies involved in the Oil \& Gas sector. Eventually, the consequences of the study will enable relevant government and private agencies to allocate appropriate resources more efficiently.

Furthermore, the proposed model might be helpful for managers to get better picture of the individual's factors that can influence the intention to adoption and commitment to implementation of BPR. This information can help company's managers to develop the most suitable and efficient strategies for BPR implementation process 
in order to improve and enhance BPR success rates by understanding the Critical Success Factors (CSFs) that can influence the rate of BPR performance success, which shall lead to gaining competitive advantage.

\section{References}

Agrawal, A., \& Cockburn, I. (2003). The anchor tenant hypothesis: exploring the role of large, local, R\&D-intensive firms in regional innovation systems. International Journal of Industrial Organization, 21(9), 1227-1253. http://dx.doi.org/10.1016/S0167-7187(03)00081-X

Ahmad, H., Francis, A., \& Zairi, M. (2007). Business process reengineering: critical success factors in higher education. Business Process Management Journal, 13(3), 451-469. http://dx.doi.org/10.1108/14637150710752344

Al-Mashari, M., Zairi, M., \& Al-Mudimigh, A. (2010). ERP implementation: An integrative methodology. Paper presented at the I3E 01 Proceedings of the IFIP Conference on Towards The E-Society: E-Commerce, E-Business and E-Government.

Albadvi, A., Keramati, A., \& Razmi, J. (2007). Assessing the impact of information technology on firm performance considering the role of intervening variables: organizational infrastructures and business processes reengineering. International Journal of Production Research, 45(12), 2697-2734. http://dx.doi.org/10.1080/00207540600767780

Armistead, C., \& Machin, S. (1997). Implications of business process management for operations management. International Journal of Operations \& Production Management, 17(9), 886-898. http://dx.doi.org/10.1108/01443579710171217

Baer, M., \& Frese, M. (2003). Innovation is not enough: Climates for initiative and psychological safety, process innovations, and firm performance. Journal of Organizational Behavior, 24(1), 45-68. http://dx.doi.org/10.1002/job.179

Banutu-Gomez, M. B. (2002). Leading and managing in developing countries: Challenge, growth and opportunities for twenty-first century organisations. Cross Cultural Management: An International Journal, 9(4), 29-41. http://dx.doi.org/10.1108/13527600210797479

Berthon, P., Mac Hulbert, J., \& Pitt, L. (2004). Innovation or customer orientation? An empirical investigation. European Journal of Marketing, 38(9/10), 1065-1090. http://dx.doi.org/10.1108/03090560410548870

Black, S. A., \& Porter, L. J. (1996). Identification of the Critical Factors of TQM*. Decision Sciences, 27(1), 1-21. http://dx.doi.org/10.1111/j.1540-5915.1996.tb00841.x

Brown, S. P., \& Leigh, T. W. (1996). A new look at psychological climate and its relationship to job involvement, effort, and performance. J. Appl Psychol, 81(4), 358-368. http://dx.doi.org/10.1037/0021-9010.81.4.358

Caron, J. R., Jarvenpaa, S. L., \& Stoddard, D. B. (1994). Business reengineering at CIGNA Corporation: experiences and lessons learned from the first five years. Mis Quarterly, 233-250. http://dx.doi.org/10.2307/249617

Champy, J. (1990). Organizational revisionism. CIO Magazine, 20.

Champy, J. A., \& Nohria, N. (1996). Fast forward: The best ideas on managing business change. Harvard Business Press.

Chapman, C. S., \& Kihn, L. A. (2009). Information system integration, enabling control and performance. Accounting, Organizations and Society, 34(2), 151-169. http://dx.doi.org/10.1016/j.aos.2008.07.003

Chiplunkar, C., Deshmukh, S., \& Chattopadhyay, R. (2003). Application of principles of event related open systems to business process reengineering. Computers \& Industrial Engineering, 45(3), 347-374. http://dx.doi.org/10.1016/S0360-8352(03)00029-9

Cotte, J., \& Wood, S. L. (2004). Families and innovative consumer behavior: A triadic analysis of sibling and parental influence. Journal of Consumer Research, 31(1), 78-86. http://dx.doi.org/10.1086/383425

Davenport, T. H. (1993). Process innovation: reengineering work through information technology. Harvard Business Press.

Della Torre, E., \& Solari, L. (2012). High-performance work systems and the change management process in medium-sized firms. The International Journal of Human Resource Management, 24(13), 2583-2607. http://dx.doi.org/10.1080/09585192.2012.744337 
Den Hartog, D. N., Boon, C., Verburg, R. M., \& Croon, M. A. (2012). HRM, communication, satisfaction, and perceived performance: a cross-level test. Journal of Management.

Edward, L. N., \& Mbohwa, C. (2013). The Role of Leadership in Business Process Reengineering â€æLeaders, do you want to change? Paper presented at the Information and Knowledge Management.

Elmuti, D., \& Kathawala, Y. (2011). An Investigation Of The Human Resources Management Practices Of Japanese Subsidiaries In The Arabian Gulf Region. Journal of Applied Business Research (JABR), 7(2), $82-88$.

Evans, R. (1994). The human side of business process re-engineering. Management Development Review, 7(6), 10-12. http://dx.doi.org/10.1108/09622519410074154

Farmer, D. J. (2002). Love and un-engineering. Administrative Theory \& Praxis, 24(2), 369-380.

Fu et al. (2013). The Application of BPR in Seismic Data Processing and Interpretation Management. Recent Advances in Computer Science and Information Engineering (pp. 835-841). Springer.

Goldsmith, R. E., \& Hofacker, C. F. (1991). Measuring consumer innovativeness. Journal of the Academy of Marketing Science, 19(3), 209-221. http://dx.doi.org/10.1007/BF02726497

Griffith, S. J., \& Steele, M. T. (2005). On Corporate Law Federalism: Threatening the Thaumatrope. The Business Lawyer, 1-23.

Grover, V., \& Markus, M. L. (2008). Business process transformation. ME Sharpe.

Hammer, M. (1990). Reengineering work: don't automate, obliterate. Harvard Business Review, 68(4), 104-112.

Hammer, M., \& Champy, J. (2009). Reengineering the Corporation: Manifesto for Business Revolution. Harper Collins.

Hammer, M., Champy, J., \& Le Seac'h, M. (1993). Le reengineering (Vol. 93). Dunod.

Hammer, M., \& Stanton, S. (1999). How process enterprises really work. Harvard Business Review, 77, $108-120$.

Herzog, N. V., Tonchia, S., \& Polajnar, A. (2009). Linkages between manufacturing strategy, benchmarking, performance measurement and business process reengineering. Computers \& Industrial Engineering, 57(3), 963-975. http://dx.doi.org/10.1016/j.cie.2009.03.015

Hjalager, A. M. (2010). A review of innovation research in tourism. Tourism Management, 31(1), 1-12. http://dx.doi.org/10.1016/j.tourman.2009.08.012

Hopkins, H. D. (2003). The response strategies of dominant US firms to Japanese challengers. Journal of Management, 29(1), 5-25. http://dx.doi.org/10.1177/014920630302900105

Hurt, H. T., Joseph, K., \& Cook, C. D. (1977). Scales for the measurement of innovativeness. Human Communication Research, 4(1), 58-65. http://dx.doi.org/10.1111/j.1468-2958.1977.tb00597.x

Jurison, J. (1999). Software project management: the manager's view. Communications of the AIS, 2, 2.

Khalil, M. M., Tremoleda, J. L., Bayomy, T. B., \& Gsell, W. (2013). Molecular SPECT imaging: an overview. International Journal of Molecular Imaging.

Lozano, R. (2012). Are companies planning their organisational changes for corporate sustainability? An analysis of three case studies on resistance to change and their strategies to overcome it. Corporate Social Responsibility and Environmental Management.

Meadows, M., \& Merali, Y. (2003). Process Improvement with Vision: A Financial Services Case Study. Systemic Practice and Action Research, 16(3), 171-195. http://dx.doi.org/10.1023/A:1023807821671

Mengesha, G. H., \& Common, R. K. (2006). Civil service reform in Ethiopia: Success in two ministries. Hull university business school (HUBS).

Midgley, D. F., \& Dowling, G. R. (1978). Innovativeness: the concept and its measurement. Journal of Consumer Research, 229-242. http://dx.doi.org/10.1086/208701

Mohapatra, S. (2013). The Need for BPR and Its History Business Process Reengineering (pp. 39-49): Springer.

Motwani, J., \& Akbulut, A. Y. (2009). ERP Integration into Existing Courses: A Three-Step Approach. Encyclopedia of Information Communication Technology. http://dx.doi.org/10.1007/978-1-4614-6067-1

Oppenheim, B. W. (2011). A Brief History of Recent Management Paradigms. Lean for Systems Engineering 
with Lean Enablers for Systems Engineering, 9-13. http://dx.doi.org/10.1002/9781118063996.ch2

Ozcelik, Y. (2010). Do business process reengineering projects payoff? Evidence from the United States. $\begin{array}{lllll}\text { International Journal of Project } & \text { Management, }\end{array}$ http://dx.doi.org/10.1016/j.ijproman.2009.03.004

Paper, D., \& Chang, R. D. (2005). The state of business process reengineering: a search for success factors. Total Quality Management \& Business Excellence, 16(1), 121-133. http://dx.doi.org/10.1080/1478336042000309907

Peccei, R., Giangreco, A., \& Sebastiano, A. (2011). The role of organisational commitment in the analysis of resistance to change: Co-predictor and moderator effects. Personnel Review, 40(2), 185-204. http://dx.doi.org/10.1108/00483481111106075

Ranganathan, C., Teo, T. S., \& Dhaliwal, J. (2011). Web-enabled supply chain management: Key antecedents and performance impacts. International Journal of Information Management, 31(6), 533-545. http://dx.doi.org/10.1016/j.ijinfomgt.2011.02.004

Rich, N., \& Bateman, N. (2003). Companiesâ€ $€^{\mathrm{TM}}$ perceptions of inhibitors and enablers for process improvement activities. International Journal of Operations \& Production Management, 23(2), 185-199. http://dx.doi.org/10.1108/01443570310458447

Rivard, S. (2004). Information Technology and Organizational Transformation: Solveing the Management Puzzle. Routledge.

Schein, R. H. (2004). Cultural traditions. A Companion to Cultural Geography, 11. http://dx.doi.org/10.1002/9780470996515.ch2

Shen, C. W., \& Chou, C. C. (2010). Business process re-engineering in the logistics industry: a study of implementation, success factors, and performance. Enterprise Information Systems, 4(1), 61-78. http://dx.doi.org/10.1080/17517570903154567

Simchi-Levi, D., Kaminsky, P., \& Simchi-Levi, E. (2003). Cadeias de Suprimentos Projeto E Gestao: Grupo A.

Trkman, P. (2010). The critical success factors of business process management. International Journal of Information Management, 30(2), 125-134. http://dx.doi.org/10.1016/j.ijinfomgt.2009.07.003

Zaltman, G., Angelmar, R., \& Pinson, C. (1971). Metatheory in Consumer Behavior Research Rap Session Position Paper. Paper presented at the Proceedings of the Second Annual Conference of the Association for Consumer Research.

\section{Copyrights}

Copyright for this article is retained by the author(s), with first publication rights granted to the journal.

This is an open-access article distributed under the terms and conditions of the Creative Commons Attribution license (http://creativecommons.org/licenses/by/3.0/). 